\title{
Yield of chicory 'Folha larga' and 'Pão de açúcar' according to planting density
}

\section{Rendimiento de achicoria 'Folha larga' y 'Pão de açúcar' en función de la densidad de plantación}

JOARA SECCHI CANDIAN ${ }^{1,2}$

MATEUS VINICIUS NARCISO REDIGOLO 1

WALTER LUIZ DE PROENÇA ANTUNES' 1

ANTONIO ISMAEL INÁCIO CARDOSO'1

Chicory plantation.

Photo: E. Alves

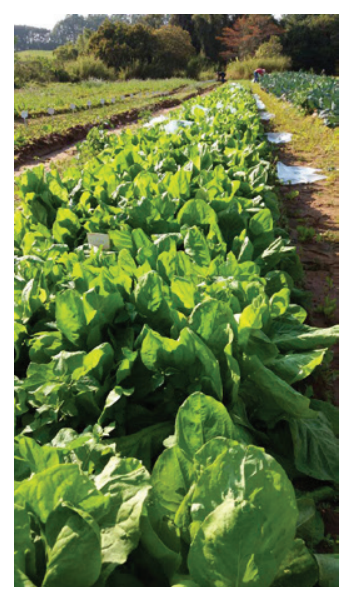

\begin{abstract}
Plant density directly influences the productive potential of crops, and the best density is not the same for all cultivars. Because of a lack of research in this area with chicory, this study aimed to evaluate the effect of plant density on the production of two chicory cultivars, Folha Larga and Pão de Açúcar. Seven planting densities were evaluated (444,444; 370,370; 333,333; 277,778; 266,667; 222,222 and 185,185 plants/ha); the experiment design used a randomized block design with four replications. The fresh weight, plant height, leaf number and yield were evaluated. Despite the fact that density did not influence plant height, mass reduction was observed in the fresh weight and number of leaves per plant and there was an increase in yield of both cultivars with the higher density.
\end{abstract}

Additional key words: Cichorium intybus L., fresh weight, spacing.

\section{RESUMEN}

La densidad de planta influye directamente en el potencial productivo de los cultivos y la mejor puede no ser la misma para todos. Debido a la falta de investigación en esta línea con achicoria, con el objetivo de estudiar el efecto de la densidad de plantas sobre el rendimiento de los dos cultivares de achicoria, de Folha Larga y Pão

1 Faculdade de Ciências Agronômicas de Botucatu, Departamento de Horticultura, Universidade Estadual Paulista "Júlio de Mesquita Filho", Botucatu-SP (Brazil). ORCID Candian, J.S.: 0000-0001-8892-1741; ORCID Redigolo, M.V.N.: 0000-0002-6007-092X; ORCID Antunes, W.L.d.P.: 0000-0002-5552-427X; ORCID Cardoso, A.I.I.: 0000-0003-32519491

2 Corresponding author. joara@live.com 
de Açúcar. Se evaluaron siete densidades de plantas (444.444, 370.370, 333.333, 277.778, 266.667, 222.222 y 185.185 plantas/ha), en un diseño de bloques al azar con cuatro repeticiones. Se evaluaron el peso fresco, altura de planta, número de hojas y la rendimiento. A pesar de la densidad no influyó en altura de la planta, había una disminución en el peso fresco y el número de hojas por planta y hubo un aumento de la rendimiento de los dos cultivares de mayor densidad.

Palabras clave adicionales: Cichorium intybus L., peso fresco, espaciamiento.

Received for publication: 07-02-2017 Accepted for publication: 30-09-2017

\section{INTRODUCTION}

Chicory (Cichorium intybus L.) has elongated leaves and a slightly bitter taste. It belongs to the Asteraceae family, which covers the most consumed vegetables and herbs with popular acceptance. The most common cultivars are Folha Larga, which does not form a head and has a clear green color, and 'Pão de Açúcar', forming an elongated head with close leaves and a bright green color (Filgueira, 2008).

The use of the ideal spacing is one of the factors that optimize production since more plants per unit area can mean greater productivity. However, this increase in plants in a given space has limits because of increased competition and can hinder individual development, leading to falls in yield and/or quality if it is not used properly (Corrêa et al., 2014). When increasing the number of plants, there is an increased competition for water, light and nutrients, resulting in reduced photosynthesis, decreased growth, and direct interferrence with the production and quality of the product.

The productive potential of each cultivar is tied to the use of the area because the planting density has a direct influence on architecture and plant height, fresh and dry weight and yield (Takahashi and Cardoso, 2014). In addition, consolidation optimizes the ability to suppress invasive plants as a result of soil shading negatively interfering with the early growth and development (Carvalho and Guzzo, 2008). However, there are few studies on the herbaceous plants of the Asteraceae family, and the vast majority is restricted to lettuce (Takahashi and Cardoso, 2014).

It was observed that density may or may not influence the height of plants depending on the farm.
Keiko and Cardoso (2014) reported that despite the fact that population does not affect the height of the mini lettuce Renoir, an increase in the density increased the height of Sartre. The productivity tended to increase, up to a certain point, as reported Lopes et al. (2008), when they observed an increase in the total yield and commercial roots of carrot. However, it is worth mentioning that excess thickening resulting from high competition between plants can harm the development (Purquerio et al., 1997). In snap beans, Pereira et al. (2003) observed that the cultivar Coralina was reduced by $6 \mathrm{t}$ ha $\mathrm{a}^{-1}$ when the population was increased, while the cultivar Tourmaline did not differ. It was also observed that in addition to physical qualities, the population affected the physico-chemical qualities of food, as reported by Bezerra Neto et al. (2006) who observed a reduction in firmness, vitamin $C$ and $\beta$-carotene in carrots, and vitamin $C$ and total chlorophyll in lettuce leaves with an increased density.

For Brazilian conditions, research papers on chicory in the 1990s and in the past decade were published for this crop (Godoi et al., 2007). However, there is a lack of research on chicory plant density for all cultivars, especially Pão de Açúcar. Filgueira (2008) reported that the ideal spacing for cultivation is 25 to $30 \mathrm{~cm}$ between rows and 8 to $10 \mathrm{~cm}$ between plants. Trani et al. (1996), in a fertilizer recommendation bulletin for the state of São Paulo, indicated $25-30 \mathrm{~cm} x$ $10-15 \mathrm{~cm}(222,222$ to 400,000 plants/ha).

Because of the lack of research on this area for chicory, this study aimed to evaluate the effect of plant density on the yield of two cultivars, Folha Larga and Pão de Açúcar. 


\section{MATERIAL AND METHODS}

The experiments were conducted in São Manuel, SP (Brazil) at $22^{\circ} 46^{\prime} \mathrm{S}$ and $48^{\circ} 34^{\prime} \mathrm{W}$ and $740 \mathrm{~m}$ a.s.l. The climate of São Manuel área, using as the criteria adopted by Koppen and based on meteorological observations, is CFA (clima temperado mesotérmico) (Cunha and Martins, 2009).

Two experiments were conducted simultaneously, each with a different plant variety: 'Folha Larga' and 'Pão de Açúcar'. Sowing was done on the April 4th, 2014 using polypropylene trays with 200 cells filled with the commercial substrate Carolina Soil and the transplant was done on May 12 ${ }^{\text {th }}, 2014$.

Seven treatments $(0.25 \times 0.09,0.25 \times 0.12,0.25 \times 0.15$, $0.25 \times 0.18, \quad 0.30 \times 0.09, \quad 0.30 \times 0.12, \quad 0.30 \times 0.15$ and $0.30 \times 0.18 \mathrm{~m}$ ) (densities of 444,444; 370,370; 333.333; 277,$778 ; 266,667 ; 222,222$ and 185,185 plants/ha) were used in a randomized block design with four replications. The densities were obtained with the combination of two row spacings $(25$ and $30 \mathrm{~cm}$ ) and four plant spacings $(9,12,15$ and $18 \mathrm{~cm})$, a total of seven densities, based on the ideal spacing range of Filgueira (2008) and Trani et al. (1997), considering that the treatments $30 \times 15 \mathrm{~cm}$ and $25 \times 18 \mathrm{~cm}$ had the same density. The plots consisted of 40 plants, evaluating 10 plants.

The soil is a Dystrophic Red Latosol, with the following results obtained from chemical analysis prior to experiment installation (Tab. 1). For plant fertilizer, $2 \mathrm{~kg} \mathrm{~m}^{-2}$ of commercial organic compound (PROVASO $\left.{ }^{\circledR}\right)$ and $100 \mathrm{~g} \mathrm{~m}^{-2} 4-14-8$ (NPK) and cover (9 g $\mathrm{m}^{-2}$ urea every $7 \mathrm{~d}$ ) were applied, as recommended in Bulletin 100 for the State of São Paulo (Raij et al., 1997). The soil was graded and the fertilizers were incorporated with the help of a rotary hoe.

The cultural practices performed were: thinning on a tray, leaving only one seedling per cell, weeding the flowerbeds and sprinkler irrigation. There was no occurrence of pests or diseases.

A single harvest was done $44 \mathrm{~d}$ after transplantation; the following characteristics are evaluated: number of still green leaves, height and fresh weight and productivity, calculated for each density. Height was measured as the distance from the soil to the highest part of the plant. For the mass, all of the leaves were weighed with a precision scale.
Joint analysis of the experiments was performed to compare the two cultivars and analysis of variance and regression were done to evaluate the effect of the planting densities, using the Sisvar program (Ferreira, 2011).

\section{RESULTS AND DISCUSSION}

The cultivar Folha Larga had a higher height (47.4 $\mathrm{cm})$ than 'Pão de Açúcar' $(43.2 \mathrm{~cm}$ ) (Tab. 2). Despite reporting lower values than those of the present study, Novo et al. (2003) also observed a greater plant height for the cultivar Folha Larga $(35.8 \mathrm{~cm})$ than 'Pão de Açúcar' $(28.7 \mathrm{~cm})$, using a spacing of $0.03 \times 0.20 \mathrm{~m}$. Perhaps these lower values were associated with the smaller spacing between plants, only $3 \mathrm{~cm}$, which provided greater competition and lower development of each plant individually. These authors found that cultivating Folha Larga had a greater vertical development as compared to 'Pão de Açúcar', which showed the highest lateral growth, forming a "head"; moreover, the experiment was conducted in a greenhouse and under different nitrogen levels, which may have also influenced the results.

Plant height was not influenced by the densities, with an overall average of $44.9 \mathrm{~cm}$. In some cases, it was observed that reducing the space between plants may cause shading since there is increased competition for light. Furthermore, increased competition may also reduce the availability of nutrients for each individual plant and hinder development, leading to the formation of smaller plants (Taiz and Zeiger, 2004). In the present study, these effects from planting density were not observed. There was no research on chicory for comparison. However, there is a lot of research on lettuce, which belongs to the same family. Castoldi et al. (2012) observed that plant density did not affect the plant height of three varieties of mini lettuce. Takahashi and Cardoso (2014) reported that density did not affect the height of the plants from the cultivar of lettuce mini Renoir, but observed a small increase in plant height $(0,06 \mathrm{~m})$ in the cultivar Sartre with an increased density. Moniruzzaman (2006) reported an increased plant height in different lettuce cultivars with an increased plant density. Therefore, it was observed that the response time may vary according to the cultivar and, for chicory cultivars, the density did not influence this characteristic of the plants. 
Table 1. Results obtained from the chemical analysis. São Manuel, UNESP-FCA, 2014.

\begin{tabular}{|c|c|c|c|c|c|c|c|c|c|c|c|}
\hline $\mathrm{pH}$ & M.O. & $P_{\text {resina }}$ & $\mathrm{Al}^{3+}$ & $\mathrm{H}+\mathrm{Al}$ & $K$ & $\mathrm{Ca}$ & $\mathrm{Mg}$ & SB & CTC & V\% & $S$ \\
\hline $\mathrm{CaCl}_{2}$ & $\mathrm{~g} \mathrm{dm}^{-3}$ & $\mathrm{mg} \mathrm{dm}^{-3}$ & & & 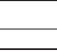 & $\mathrm{mol}_{\mathrm{c}} \mathrm{d}$ & & & & & $\mathrm{mg} \mathrm{dm}^{-3}$ \\
\hline 5.5 & 15 & 201 & --- & 19 & 2.7 & 36 & 9 & 47 & 67 & 71 & --- \\
\hline
\end{tabular}

Table 2. Plant height, fresh weight and productivity for the chicory cultivars Folha Larga and Pão de Açúcar. São Manuel, UNESP-FCA, 2014.

\begin{tabular}{|l|c|c|c|}
\hline \multicolumn{1}{|c|}{ Cultivars } & Height $(\mathrm{cm})$ & Fresh weight $(\mathrm{g})$ & ${\text { Productivity }\left(\mathrm{t}^{\mathrm{i}}{ }^{-1}\right)}^{3.85 \mathrm{~b}}$ \\
\hline Folha Larga & $47.4 \mathrm{a}$ & $136.29 \mathrm{~b}$ & $5.68 \mathrm{a}$ \\
\hline Pão de Açúcar & $42.3 \mathrm{~b}$ & $203.59 \mathrm{a}$ & 0.19 \\
\hline Standard error & 0.69 & 6.35 & 22.20 \\
\hline CV (\%) & 8.70 & 21.14 & \\
\hline
\end{tabular}

Means followed by the same letter in the columns did not differ by Tukey test at $5 \%$ probability.

Table 3. Number of leaves per plant for the chicory cultivars Folha Larga and Pão de Açúcar according to plant density. São Manuel, UNESP-FCA, 2014.

\begin{tabular}{|l|c|c|c|c|c|c|c|}
\hline \multicolumn{1}{|c|}{ Cultivars } & \multicolumn{9}{c|}{ Plant density (plants/ha) } \\
\hline & $185,185.2$ & $222,222.2$ & $266,666.7$ & $277,777.8$ & $333,333.3$ & $370,370.4$ & $444,444.4$ \\
\hline Folha Larga & $21.67 \mathrm{a}$ & $14.79 \mathrm{a}$ & $15.42 \mathrm{a}$ & $14.50 \mathrm{a}$ & $11.42 \mathrm{a}$ & $12.92 \mathrm{a}$ & $13.58 \mathrm{a}$ \\
\hline Pão de Açúcar & $11.75 \mathrm{~b}$ & $11.88 \mathrm{~b}$ & $11.17 \mathrm{~b}$ & $11.42 \mathrm{a}$ & $11.17 \mathrm{a}$ & $12.22 \mathrm{a}$ & $10.09 \mathrm{~b}$ \\
\hline Standard error & 1.21 & 0.85 & 1.21 & 1.21 & 1.21 & 1.21 & 1.21 \\
\hline CV (\%) & \multicolumn{9}{|c|}{18.34} \\
\hline
\end{tabular}

Means followed by the same letter in the columns do not differ by Tukey test at $5 \%$ probability.

The number of leaves per plant was the only characteristic where we obtained a significant interaction between the factors plant density and cultivar. For most densities, the cultivar Folha Larga had more leaves than 'Pão de Açúcar' (Tab. 3). Again the values obtained in this study were higher than those of Novo et al. (2003), who obtained averages of 6.93 and 7.05 leaves per plant for 'Folha Larga' and 'Pão de Açúcar', respectively, at a much higher density $(1,666,666$ plants/ha). For density, there was no effect on Pão de Açúcar, averaging 11.5 leaves per plant. Moreover, there was a reduction in the number of leaves on 'Folha Larga' with increasing density (Fig. 1). This decrease in the number of leaves can be explained by the increased competition between plants for water, light and nutrients, limiting the formation of new leaves.

The higher the planting density, the less fresh weight per plant in both cultivars (Fig. 1), probably because of increased competition for water, light, and nutrients, among other factors. On the other hand, the yield increased with the higher density of the plants (Fig. 1), despite the reduction in the fresh mass of each plant. The cultivar ' Pão de Açúcar' had a higher fresh weight and productivity (Tab. 2) than 'Folha Larga', probably because of the formed head, while the 'Folha Larga' had taller plants (Tab. 2). Also, Novo et al. (2003) observed a higher fresh weight and productivity in the cultivar 'Pão de Açúcar' (66.7 t ha-1) than 'Folha Larga' (59.5 t ha-1).

Therefore, the greatest number of plants favored increased productivity within this density range. The higher density also helped cover the soil faster, causing weed choking (Flesch and Vieira, 2004), which could favor higher yields (Carvalho and Guzzo, 2008). However, it is important to note that chicory, and most leafy vegetables, is sold per unit or stack or crate, and rarely by weight. Thus, the increase in productivity becomes more important than the reduction in fresh weight per plant since density means increasing the number of plants per area. However, 


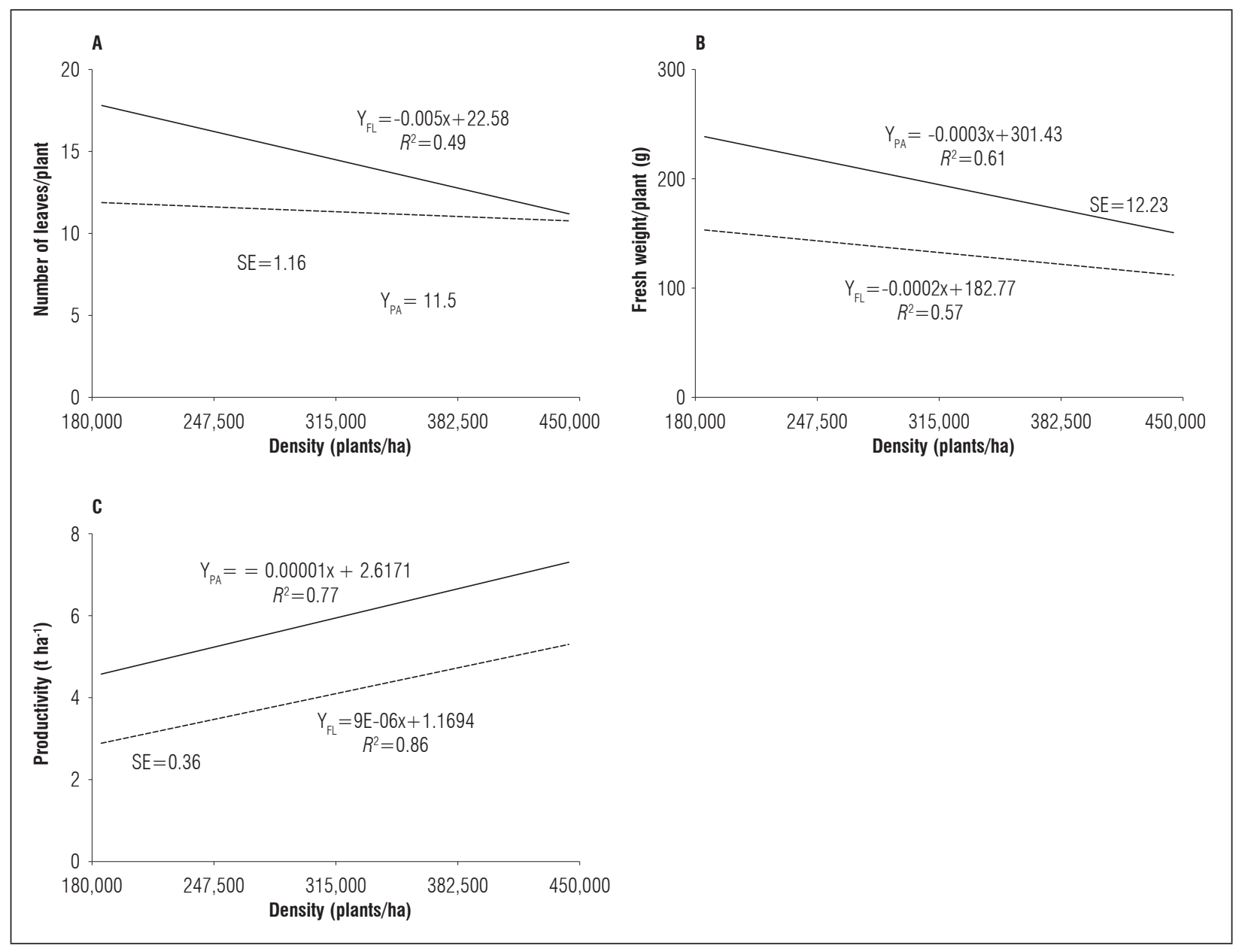

Figure 1. Number of leaves per plant, fresh weight and productivity of the chicory 'Pão de Açúcar' $\left(\mathrm{Y}_{\mathrm{PA}}\right)$ and 'Folha Larga' $\left(\mathrm{Y}_{\mathrm{FL}}\right)$ according to planting density. São Manuel, UNESP-FCA, 2014.

one must be attentive to the market because there is a lower limit on the size of the plants to be sold individually or in packs.

Pereira et al. (2003) reported a reduction of up to 6 $\mathrm{t} \mathrm{ha} \mathrm{a}^{-1}$ when increasing the plant population of snap beans. In carrots, the increased density resulted in an increased overall productivity and commercial roots, despite having decreased the weight average. The root length was reduced, increasing the percentage of short roots (Lopes et al., 2008). According to Oliveira et al. (2011), the total biomass is positively related to density. Santos et al. (2013), comparing chicory 'Catalonha', 'Folha Amarela', 'Folha Larga' and 'Pão de Açúcar', at a density of 112,000 plants/ha, found that there was no difference between the fresh and dry weight, height of plants, number of leaves and productivity. However, it is noteworthy that the density used by these authors was much lower than in this study, which ranged from 185,185 to 444,444 plants per hectare.

Usually, with an increase in planting density, the vegetative/productive characteristics of various vegetables are reduced, such as root, lettuce, couliflower, gherkin, rocket and row (Purquerio et al., 2007; Carvalho and Guzzo, 2008; Oliveira et al., 2010; Silva et al., 2011; Pôrto et al., 2012; Corrêa et al., 2014; Takahashi and Cardoso, 2014). Most of this study also demonstrated increased productivity with increases in plant density despite having a threshold at which loss from competition between plants is greater than the gain from increasing the number of plants. However, this density has a limit which, when reached, the competition between plants is so great that the reduction in the vegetative/productive characteristics 
is not offset by the larger number of plants. This study apparently did not reach this limit. However, the higher planting densities started to have a few plants with the beginnings rotting in the base, probably because of the lower ventilation and increased moisture at the base, once the sprinkler irrigation was the same for all plants. Since the precipitation during the study period was almost nil, this decay was not widespread.

It should be noted that the management was the same, regardless of density, including fertilization. This increase in the number of plants may require higher amounts of nutrients per plant, as reported by Purquerio et al. (2007) in rocket. However, different levels of fertilization have not been tested since, in this study, the fertilization was the same for all treatments, according to the recommendation of Raij et al. (1997), which is to lower the densities evaluated in this experiment. At higher densities, the availability of nutrients may be reduced for each plant, and can be a factor responsible for a reduction in yield per plant. Perhaps with higher doses of fertilizers it would be possible to increase the yield per plant by reducing the effect of competition for nutrients.

\section{CONCLUSION}

Pão de Açúcar had a greater yield than 'Folha Larga' despite having lower plants.

The number of leaves of each variety was influenced by the plant population; 'Pão de Açúcar' was lower than 'Folha Larga' for the majority of the densities.

An increased planting density increased the productivity of the chicory 'Folha Larga' and 'Pão de Açúcar' although it reduced the fresh weight of each plant.

Conflict of interests: the manuscript was prepared and reviewed with the participation of the authors, who declare that there exists no conflict of interestthat puts in risk the validity of the presented results.

\section{BIBLIOGRAPHIC REFERENCES}

Bezerra Neto, F., A.P. Barros Júnior, E.O. Silva, M.Z. Negreiros, E.Q. Oliveira, L.M. Silveira, M.J.T. Câmara, and G.H.S. Nunes. 2006. Qualidade nutricional de cenoura e alface cultivadas em Mossoró-RN em função da densidade populacional. Hortic. Bras. 24, 476-480. Doi: 10.1590/S0102-05362006000400016
Carvalho, L.B. and C.D. Guzzo. 2008. Increased beet density in weed management. Planta Daninha 26, 73-82. Doi: 10.1590/S0100-83582008000100008

Castoldi, R., E.A. André, L.T. Braz, and H.C.O. Charlo. 2012. Performance of cultivars of crisp mini-lettuce with respect to ground cover and spacing, in three planting times. Acta Hortic. 936, 379-384. Doi: 10.17660/ ActaHortic.2012.936.50

Corrêa, C.V., A.I.I Cardoso, L.G. Souza, W.L.P. Antunes, and L.A. Magolbo, 2014. Yield of beet depending on spacing. Hortic. Bras. 32, 140-144.

Cunha, A.R. and D. Martins. 2009. Classificação climática para os municípios de Botucatu e São Manoel, SP. Irriga 14, 1-11. Doi: 10.15809/irriga.2009v14n1p01

Ferreira, D.F. 2011. Sisvar - Sistema de análise de variância. Versão 5.3. 2011. UFLA, Lavras-MG, Brazil.

Filgueira, F.A.R. 2008. Novo manual de olericultura: agrotecnologia moderna na produção e comercialização de hortaliças. $3^{\text {rd }}$ ed. Ed. UFV, Viçosa, Brazil.

Flesch, R.D. and L.C. Vieira. 2004. Spacing and plant populations of hybrids with different cycles in the west of Santa Catarina, Brasil. Ciência Rural 34(1), 25-31. Doi: 10.1590/S0103-84782004000100005

Godoi, R.S., J.L. Andriolo, J.C.C. Madalóz, D.I. Janisch, and C.A.P. Barros. 2007. Growth and yield of chicory plants under total $\mathrm{N}$ concentrations containing $\mathrm{NH}_{4}^{+}$ in the nutrient solution. Ciência Rural 37, 1170-1173. Doi: 10.1590/S0103-84782007000400043

Lopes, W.A.R., M.Z Negreiros, T.M.S. Teófilo, S.S.V. Alves, C.M. Martins, G.H.S Nunes, and L.C. Grangeiro. 2008. Produtividade de cultivares de cenoura sob diferentes densidades de plantio. Rev. Ceres 55(5), 482-487.

Moniruzzaman, M. 2006. Effects of plant spacing and mulching on yield and profitability of lettuce (Lactuca sativa L.). J. Agric. Rural Dev. 4, 107-111.

Novo, M.C.S.S., P.E. Trani, and K. Minami. 2003. Performance of three chicory cultivars grown in greenhouse. Hortic. Bras. 21(1), 84-87.

Oliveira, A.P., J.A. Silva, A.N.P. Oliveira, D.F. Silva, R.R. Santos, and N.V. Silva. 2010. Gherkin yield influenced by spacing between rows and between plants in a row. Hortic. Bras. 28(3), 344-347. Doi: 10.1590/ S0102-05362010000300017

Oliveira, R.G., L.F.O.S. Rodrigues, S. Seabra Jr., M.B. Silva, M.T.R. Nohama, A.M. Inagaki, and M.C.M. Nunes. 2011. Performance of lettuce cultivars in different densities under greenhouse and open field. Hortic. Bras. 29, 110-118.

Pereira, A.V., R.F. Otto, and M.Y. Reghin. 2003. Respostas do feijão-vagem cultivado sob proteção com agrotêxtil em duas densidades de plantas. Hortic. Bras. 21(3) 564-569. Doi: 10.1590/S0102-05362003000300030 
Pôrto, D.R.Q., A.B. Cecílio Filho, B.L.A Rezende, A.P Barros Júnior, and G.S. Silva. 2012. Population density and planting time on the growth and yield of cauliflower cv. Verona. Caatinga 25, 92-98.

Purquerio, L.F.V., L.A.R. Demant, R. Goto, and R.L. Villas -Boas. 2007. Effect of side dressing nitrogen fertilization and distance between plants on yield of rocket salad. Hortic. Bras. 25, 464-470. Doi: 10.1590/ S0102-05362007000300028

Raij, B.V., H. Cantarella, J.A. Quaggio, and A.M.C. Furlani. 1997. Recomendações de adubação e calagem para o estado de São Paulo. $2^{\text {nd }}$ ed. Instituto Agronômico e Fundação IAC, Campinas, Brazil.

Santos, F., P.E., M.C.S.S. Trani Novo, and F.A. Passos. 2013. Agronomic performance of four chicory cultivars. Hortic. Bras. 31, 153-156. Doi: 10.1590/ S0102-05362013000100024
Silva, G.S., A.B. Cecílio Filho, J.C. Barbosa, and A.U. Alves. 2011. Growth and yield of red cabbage as affected by distances between rows and plants. Bragantia 70, 538543. Doi: 10.1590/S0006-87052011000300008

Taiz, L. and E. Zeiger. 2004. Fisiologia vegetal. Artmed, Porto Alegre, Brazil.

Takahashi, K. and A.I.I. CardosoI. 2014. Plant density in production of mini lettuce cultivars in organic system management. Hortic. Bras. 32, 342-347. Doi: 10.1590/ S0102-05362014000300017

Trani, P.E., H. Nagai, F.A. Passos, and J.A. Azevedo Filho. 1996. Alface, almeirão, chicória, escarola, rúcula e agrião d'água. In: Raij, J.B. van, H. Cantarella, J.A. Quaggio, and A.M.C. Furlani (eds.). Recomendações de adubação e calagem para o Estado de São Paulo. IAC Boletim Técnico 100, 168-169. Instituto Agronômico, Campinas, Brazil. Doi: 10.1590/ S0102-05362014000300017 